$$
\ddot{x}+\omega_{0}^{2} x+\mu F(x)=r \cos \omega t
$$

$F(x)$ が采の降伏状態を表わ方。 らのずれを表わすパラメータで， $r=0(\mu)$ とする. この方程式の超調和共振が经生する籍团の振斯解䘮求 める. その方法は Krylov-Bogoliubov のパラメータ 徐变化法を用いる.

$$
x=A_{1} \cos \theta(t)+A_{3}(t) \cos \left\{3 \theta(t)-\varphi_{3}(t)\right\}
$$

とおいて， $A_{1} ， \varphi_{1}$ は時間に然関倸とする．定常解定 求める一般式を示し，これを線形加工硬化采 $(x$ と復 原力の関係は平行四辺形の履晸を有寸る）に適用し, 数值計算例にて定常状態における3倍調波の振幅と振 動数の離調度との閔倸で図示する. また经定性の吟味 は3倍調波の定常振幅に外乱を与えた方法で検討す る.

[杉本隆尚]

\subsection{1 .3}

[82]角形平行に束将た角形パイプの自由振動〔了。 A. Fromme and A.W. Leissa, J. Acous. Soc. Amer., Pt. 2, 1970-7, Vol. 48, No. 1, p. 290 298, 図 10, 表 2]この諭文は四解断のパイプを4本束ねた形 の棈造物の振動を扱ったもので，変位に対する解とし ては直盾座摽に閣する正弦，余弦関数の積で表わす。 解をフーリエ級数で表わすた市る閉区閒，たとえば パイプ内などでフーリエ級数に展開寸る関数の偏導関 数, 項別微分などについて数学的な定理をあげる.か つ平行パイプ振動問題の埸合方，そのうちの 2 回まで 項別微分可能，もとの関数そのものは 1 回偏微分可能 で連続な部類に属する. 本研究では非周期関数を隋伴 周期関数でおきかえここれを用いて三觕関数のフーリ 工級数に屝開する．さらにこれを用いてマトリックス 固有值問題にする.すなわちフーリエ級数に関する微 分方程式を求める. その解と境界条件よりせん断振動 数, 曲げ振動数, 縦振動数がポアソン比, 縦横比など に対して計算，図示されている。また Timoshenko はり理論，ベルヌーイ・オイラーはり理論との比較も 示されているが，本論文の方法は Timoshenkoはり の理諭とよく一致している.

[杉本 隆尚]

\subsection{1 .3}

[83]薄肉球かくの強制ねじり振動と Gegenbauer 変換について [G.L. Anderson, J. Sound and Vibr., 1970-7, Vol. 12, No. 3, p. 265 274, 図 1] 球, 半球かくが自由または拘束されているときのねじり強 制振動を扱う。トルクは一様に作用する。この運動方 程式から慣性項以外の導関数をなく市ため積分変換 (Gegenbauer 変掜) を行なら。その結果は積分变換の 核に関する方程式となる。これらにより球かく、半球か くについての方程式执よびその解の一般形を示す。半 球かくの場合については像に拘束がある揚合，渮重が 作用する場合があげられる。境界条件ももち万ん核を 用いて表わされる。本諭文ではさらに解を時間だけの 関数上時間拉よじ座標の関数の和で表わし求める。 のよ5に変掺すると解は無限級数で表わされるので, その收束性が問題となるが，乙礼について若千注意が 与えられている。もとの級数が絶対収束か否かによ る. 応用として飛行機の機首のドームが空中戦によっ て変位, 荷重を受けるときの店答が訃算され，図示さ れている。

[杉本 隆尚]

\section{$534.113: 531.43$}

[84]振動するはりに適用した摩擦減衰についての 概念 [S.W.E. Earles and C.F. Beards, Int.J. Mach. Tool Des. and Res., 1970-3, Vol. 10, No. 1, p. 123〜131, 図 6] 片持はりの自由端に固体摩擦力が 作用する場合の摩擦力は振動より $\pi \mathrm{rad}$ 位相のずれ た正弦力として近似する。1サイクル中になす仕事は 0になるので，1/4 サイクルについての仕事を求め， これより1サイクルあたりの仕事量（損失）を求める. これを理論的根扴として実験により摩擦端のす心゙り振 幅を求め，さらにこれよりすべり速度の最大值を求 め，これと摩擦係数との関倸を铜と銓，鋳鉄，黄銅の 組合わせの場合について周期外力を加える位置，振得小 数について図示している，その結果は他の方法で得ら れているものと值，傾问ともよく一致している．その 他摩擦係数と比摩擦損失なども理論, 奏験につき比較 されているが，よく一致している．摩擦力をフーリエ 級数に表わされるとして取报って振動解を表わして処 理した点が成功したものと思われる。

[杉本阵尚]

\subsection{4:624.023}

〔85]マトリックス減少法による大構造物の振動モ ード [I.U. Ojalvo and M. Newman, AIAA J., 1970-7, Vol. 8, No. 7, p. 1234 1239, 図 1] 有 限要素法の忘用で, 比較的大きい樦造物の固有振動千 一ドを解くのに使われる.

$$
[A](x)=\lambda[B](x)
$$

を扱う。変位法によるときは

$$
[A]=[K],[B]=[M], \lambda=\omega^{2}
$$

となり，荷重法によるときは

$$
[A]=[M][K]^{-1}[M],[B]=[M], \lambda=1 / \omega^{2}
$$

となる. $[K]$ は風性マトリックス, $[M]$ は質量マト リックス. 本論文ではもと $n$ 個座標があったものを $n-m$ 個の拘束条件を加え， $m$ 個に隇らして計算する 方法を示す. Rayleigh の商

$$
\lambda_{R}=(y)^{T}[V]^{T}[A][V](y) /(y)^{T}[V]^{T}[B][V](y)
$$
において

$$
\lambda(j) \leqq \lambda_{R}^{(j)} \leqq \lambda^{(i+n-\imath n)} \quad j \leqq m
$$

なる性犋を利朋する，奉際には Lanczoo-Crandall の 計算法による．得られた結果は直交性から直交条件が 近似的にみたされるように修正する。乙の計算結果例 では $n=44$ のとき精度は $0.25 \%$ である。

[杉本隆尚]

\subsection{1 : 539.384 .2}

[86]任意の横荷重軸圧縮力を受ける振動はりの変 位 [R. Rondiak and M.H. Cobble, J. Sound and Vibr., 1970-8, Vol. 12, No. 4, p. 411 419, 図 12, 表 4]軸圧箱力が作用する雨端固定一様断面はりの 曲げ振動の解析で, エルミート演算子

$$
L \boldsymbol{u}=d^{4} u / d x^{4}+a^{2}\left(d^{2} u / d x^{2}\right)
$$

を用い，境界条件から固有值方程式を求める. 本論文 ではまず

$$
d^{4} u / d x^{4}+a^{2}\left(d^{2} u / d x^{2}\right)=7, u
$$

なる方程式の固有优, モードを求め, その固有值を用 いて軸力が作用せず，分有横侍重が作用ずる系の方程 式に変掺して橧力，横荷重が作用する場合の解を求め る方法をとる。数值計算例では横佳重として等分布の 